\title{
DINAMIKA KELOMPOK DAN KEBERHASILAN USAHA PADA PETANI TEH DAN KOPI DI GARUT
}

\section{Group Dynamics and Business Success Tea adn Coffe Farmers in Garut}

Flora Meilfania Putri* dan Asri sulistiawati

Departemen Sains Komunikasi dan Pengembangan Masyarakat, Fakultas Ekologi Manusia, Institut Pertanian Bogor, Dramaga Bogor, 16680, Indonesia

*)E-mail: fmeilfania@gmail.com

\begin{abstract}
This research uses quantitative methods conducted by surveys using a questionnaire and qualitative data obtained through in-depth interview guides and observations. The results of this study indicate that four farming groups had members who had a majority of low lifespan and education. The majority of Poktan Berkah Tani members have recently joined the group, while Poktan Pamulihan, Melati, and Pelita VB have long joined the group. Poktan berkah tani and Melati have members who often attend training, while Poktan Pamulihan and Pelita VB are the majority of the members who attend the training. The relationship between member characteristics and group dynamics is only a few significant, as is the relationship between group dynamics and business success. The difference between coffee and tea farming groups lies in the norm, role, groupthink, and fulfillment of material needs.
\end{abstract}

Keywords: Group, Group dynamics, Business success

\begin{abstract}
ABSTRAK
Penelitian bertujuan untuk menganalisis dinamika kelompok petani kopi dan teh serta peranannya terhadap keberhasilan usaha. Penelitian menggunakan pendekatan kuantitatif dilakukan dengan metode survei menggunakan kuesioner dan data kualitatif didapatkan melalui panduan wawancara mendalam dan observasi. Hasil penelitian menunjukkan empat kelompok tani memiliki anggota yang mayoritas mempunyai umur dan pendidikan yang rendah. Mayoritas anggota Poktan Berkah Tani baru bergabung dengan kelompok, sementara Poktan Pamulihan, Melati, serta Pelita VB anggotanya sudah lama bergabung dengan kelompok. Poktan berkah tani dan Melati memiliki anggota yang mayoritas sering mengikuti pelatihan, sementara Poktan Pamulihan dan Pelita VB mayoritas anggota sedikit mengikuti pelatihan. Hubungan antara karakteristik anggota dengan dinamika kelompok hanya beberapa yang signifikan, begitu juga dengan hubungan antara dinamika kelompok dan keberhasilan usaha. Perbedaan antara kelompok tani kopi dan teh terletak di norma, peran, groupthink, dan pemenuhan kebutuhan materi.
\end{abstract}

Kata Kunci: Kelompok, Dinamika kelompok, Keberhasilan usaha 


\section{PENDAHULUAN}

\section{Latar Belakang}

Sektor pertanian, kehutanan, dan perikanan memiliki peranan yang penting dalam perekonomian Indonesia. Hal tersebut tercermin dalam kontribusi sektor ini terhadap Produk Domestik Bruto (PDB) yang menduduki urutan kedua setelah sub sektor industri pengolahan. Ketiga sektor ini menyumbang 13.14 persen atas keseluruhan PDB. Salah satu sub sektor yang cukup besar potensinya adalah pada sub sektor perkebunan. Pada data BPS (2017), kontribusi sub sektor perkebunan dalam PDB sekitar 3,47 persen atau merupakan urutan pertama di sektor pertanian, peternakan, perburuan, dan jasa pertanian. Kopi adalah salah satu komoditas hasil perkebunan yang memiliki peranan cukup penting dalam perekonomian di Indonesia. Kopi menghasilkan devisa negara selain minyak dan gas.

Berdasarkan BPS (2017), perkembangan volume dan nilai ekspor rata-rata mengalami peningkatan. Pada tahun 2011 volume ekspoer kopi sebesar 346.490 ton, tahun 2012 mengalami peningkatan menjadi 448.590 ton. Pada tahun 2016 volume ekspor menjadi 414.650 ton, dan tahun 2017 meningkat menjadi 462.800 ton. Ekspor kopi tidak bisa dilakukan oleh sembarang petani, tetapi ada persayaratan tertentu yaitu yang sudah mendapatkan penetapan sebagai ETK (Eksportir Terdaftar Kopi) Komoditas lain dari hasil perkebunan adalah komoditas teh. Perkebunan teh merupakan salah satu bentuk perkebunan yang sudah lama dibudidayakan di Indonesia.

Menurut Peraturan Menteri Pertanian (2016), komoditas teh di Indonesia berfungsi sebagai sumber penciptaan lapangan kerja di pedesaan dan mendorong berkembangnya ekonomi di wilayahwilayah tersebut. Perkembangan volume ekspor yang dicatat oleh BPS (2018), mengalami penurunan dari tahun ke tahun. Pada 2014 volume ekspor teh sebesar 66.399 ton, pada tahun 2015 mengalami penurunan menjadi 61.915 ton, pada tahun 2016 menjadi 51.319 ton, pada tahun 2018 49.038 ton.

Menurut Pemerintah Kabupaten Garut, luas perkebunan pada tahun 2013 mencapai 46.323 ha. Perkembangan produksi perkebunan rakyat dapat dilihat dari luas areal dan produksi dari berbagai komoditas yang dibudidayakan oleh masyarakat. Komoditas yang banyak dibudidayakan oleh masyarakat ada 24 jenis dan komoditas perkebunan besar terdiri dari teh, karet, kakao, kina, kelapa sawit, dan kopi.

Berdasarkan penelitian sebelumnya yang dilakukan oleh Anisi et al. (2015) dinamika kelompok memiliki hubungan dengan keberhasilan usaha. Keberhasilan dan kemunduran komoditas perkebunan yaitu kopi dan teh tidak lepas dari tingkat dinamika keompok. Dilihat dari data yang telah dipaparkan di atas dinama volume ekspor kopi yang rata-rata mengalami peningkatan dari tahun ke tahun berbanding terbalik dengan keadaan komoditas teh yang mana volume ekspor teh terus mengalami penurunan. Hal inilah yang kemudian menarik untuk dikaji serta menjadi latar belakang dalam penelitian untuk bagaimana dinamika kelompok dan keberhasilan pada petani teh dan kopi di Garut

\section{Rumusan Masalah}

Berdasarkan latar belakang di atas rumusan masalah dalam penelitian ini adalah bagaimana hubungan dinamika kelompok dengan keberhasilan usaha pada Poktan Teh dan Kopi di Desa Pamulihan dan Desa Pangauban Kecamatan Cisurupan Kabupaten Garut Jawa Barat?

\section{Tujuan Penelitian}

Berdasarkan rumusan masalah yang telah diuraikan, secara umum penelitian ini bertujuan untuk menganalisis hubungan dinamika kelompok dengan keberhasilan usaha pada Poktan Teh dan Kopi di Desa Pamulihan dan Desa Panguban Kecamatan Cisurupan Kabupaten Garut Jawa Barat. 


\section{PENDEKATAN TEORITIS Dinamika Kelompok}

Menurut Santosa (2004), dinamika diartikan sebagai tingkah laku warga yang satu secara langsung memengaruhi warga lain secara timbal balik. Dinamika berarti adanya interaksi dan interdependensi antara anggota kelompok yang satu dengan anggota kelompok yang lain secara timbal balik dan antara anggota dengan kelompok secara keseluruhan. Menurut Pratisthita et al. (2014), dinamika merupakan sesuatu yang mengandung arti kekuatan, selalu bergerak, berkembang dan dapat menyesuaikan diri secara memadai terhadap keadaan. Menurut Rimbawati et al. (2015) dinamika kelompok merupakan suatu kekuatan yang terdapat di dalam kelompok yang memengaruhi anggota dan kelompok dalam mencapai tujuan.

\section{Unsur-unsur Dinamika Kelompok}

Menurut Forsyth (2019) dalam membangun dinamika kelompok terdapat lima unsur, di antaranya: (1) Norma kelompok Keberadaan norma menurut Suminar (2008) berfungsi sebagai pedoman dalam bertingkah laku untuk menentukan perbuatan yang harus dilakukan oleh anggota dan yang ditolak oleh orang-orang disekitarnya, dimana hal tersebut mengarahkan pada pencapaian tujuan kelompok. Menurut Forsyth (2019), dalam sebuah standar kelompok mereka harus memberikan arahan dan motivasi, mengorganisasi interaksi sosial, dan membuat tanggapan orang lain dapat diprediksi dan bermakna; (2) Peran kelompok, Peran menurut Arimbawa (2004) dalam kedudukannya pada suatu posisi meliputi norma-norma yang dihubungkan dengan posisi atau temoat seseorang dalam masyarakat, dan suatu konsep tentang apa yang dapat dilakukan oleh individu dalam masyarakat sebagai organisasi, dan perilaku yang penting bagi struktur sosial masyarakat. Keberadaan kelompok tani dalam sektor pertanian mempunyai berbagai peranan penting. Menurut Istiayani (2016) peranan kelompok tani berarti fungsi, penyesuaian diri, dan proses dari suatu kelompok untuk memenuhi kebutuhan dari setiap anggotanya; (3) Kohesivitas kelompok, Tingkatan yang menunjukkan anggota kelompok saling terikat satu sama lain menunjuk pada kohesivitas kelompok. Pada hasil penelitian Novitasari (2016) menyatakan bahwa semakin kompak suatu kelompok maka anggota akan mengarah pada tujuan-tujuan kelompok yang telah ditetapkan sebelumnya; (4) Power: kekuasaan, Menurut Forsyth (2019), kekuasaan adalah kemampuan individu untuk memengaruhi individu lainnya. Beberapa individu mencapai kekuatan informasi dengan sengaja memanipulasi atau mengaburkaninformasi atau setidaknya memastikan bahwa informasi tetap rahasia bersama oleh hanya beberapa anggota kelompok saja; dan (5) Tingkat Groupthink Menurut Thomas dan John (2008), groupthink dapat terjadi akibat kohesi kelompok dan tekanan yang menyertainya untuk mencapai kesesuaian yang ekstrem. Peristiwaperistiwa penting secara historis menunjuk pada isu utama dalam groupthink, sehingga sebagai anggota kelompok tanpa sadar akan membuat suara bulat atau memecahkan masalah langsung dengan tujuan membuat keputusan terbaik.

\section{Keberhasilan Usaha}

Kegiatan dalam setiap usaha memiliki tujuan akhir adalah untuk mencapai suatu kebehasilan. Keberhasilan dalam suatu usaha tidak lepas dari pengkajian sistem pengembangan usaha dengan memperhatikan tujuan yang berkenaan dengan proses dan hasil usaha yang akan dicapai. Tujuan tersebut menurut Reijntjes et al. (1999) dilihat dari keberhasilan usaha dalam pemenuhan kebutuhan materi dan pemenuhan kebutuhan sosial. Keberhasilan dalam pemenuhan materi dilihat dari produktivitas suatu usaha. Produktivitas tersebut merupakan hasil persatuan lahan, tenaga kerja, modal, waktu atau input lainnya (seperti uang tunai, energy, air dan unsur hara). Selain pemenuhan kebutuhan materi, keberhasilan usaha juga dapat dinilai dari pemenuhan kebutuhan sosial. Pemenuhan kebutuhan sosial digolongkan menjadi identitas, keamanan, dan kesinambungan.

\section{PENDEKATAN LAPANG}

\section{Metode Penelitian}

Penelitian ini menggunakan penelitian kuantitatif yang didukung dengan data kualitatif. Penelitian kuantitatif dilakukan dengan survei menggunakan kuesioner dengan pemilihan responden anggota kelompok tani teh dan kopi. Metode yang digunakan untuk memperoleh data kualitatif adalah dengan melakukan wawancara mendalam dibantu dengan panduan wawancara kepada informan serta pengolahan data sekunder dan observasi lapang. 


\section{Lokasi dan Waktu Penelitian}

Penelitian dilaksanakan di dua tempat yakni di Desa Pamulihan dan Desa Pangauban Kecamatan Cisurupan Kabupaten Garut Jawa Barat. Kedua desa tersebut memiliki beberapa kelompok yang secara performa sangat baik. Kelompok tani dibidang kopi yang memiliki performa baik menurut Dinas Pertanian Kabupaten Garut adalah Poktan Berkah Tani, sementara untuk poktan kopi yang memiliki performa kurang baik adalah Poktan Pamulihan. Poktan Teh yang memiliki performa baik adalah Poktan Melati dan poktan yang memiliki performa kurang baik adalah Poktan Pelita VB. Kegiatan pengambilan data ini dilaksanakan pada bulan Februari 2020 hingga Maret 2020.

\section{Jenis dan Teknik Pengumpulan Data}

Data yang digunakan dalam penelitian ini adalah data primer dan data sekunder. Data primer diperoleh langsung di lapangan dengan survei, yaitu wawancara terstruktur menggunakan instrumen kuesiner kepada respoden dan menggunakan data kualitatif yang diperoleh menggunakan wawancara mendalam kepada informan dengan menggunakan panduan wawancara. Data sekunder sebagai data pendukung diperoleh melalui berbagai sumber rujukan atau literatur berupa dokumen yang berhubungan dengan topik dinamika kelompok dan keberhasilan usaha.

\section{Teknik Penentuan Responden dan Informan}

Subjek dalam penelitiana ini ada dua yaitu informan dan responden. Pemilihan responden ditentukan dengan metode simple random sampling. Sampel dalam penelitian ini berjumlah 80 orang dari jumlah populasi 170 orang, dimana 40 orang tersebut terdiri dari 40 orang dari dua kelompok tani kopi dan 40 orang dari dua kelompok tani teh. Pemilihan informan dilakukan secara sengaja (purposive) dengan menentukan informan yang dianggap mengetahui hal-hal berkaitan dengan penelitian ini. Informan dalam penelitian ini diantaranya pengurus Poktan, pegawai Desa Pamulihan dan Desa Panguban, serta pegawai Dinas Pertanian Kabupaten Garut.

\section{Teknik Pengolahan dan Analisis Data}

Penelitian ini mempunyai dua jenis data yang diolah dan dianalisis, yaitu data kuantitatif dan data kualitatif. Data kuantitatif diolah menggunakan Microsoft Excel 2013 dan IBM SPSS Statistics 25. Hasil dari kuesioner yang didapatkan dari wawancara diterjemahkan menggunakan kode 1 untuk rendah dan 2 untuk tinggi. Kode-kode tersebut kemudian diinput menggunakan Microsoft Excel 2013 kemudian diolah menggunakan IBM Statistics 25. Data kuesioner juga di analisis dan di interpretasikan agar diketahui kesimpulan dari kuesioner tersebut. Selanjutnya hasil dari IBM Statistics 25 diuji korelasi Rank Spearman untuk mengukur hubungan antar karakteristik setiap anggota dengan dinamika kelompok dan dinamika kelompok dengan keberhasilan usaha. Penelitian ini juga di uji menggunakan Mann Whitney U, yaitu uji beda antara kelompok peani kopi dan juga teh.

Data kualitatif seperti hasil dari wawancara mendalam dianalisis melalui proses reduksi data, penyajian data, dan verifikasi. Data tersebut disajikan dalam bentuk teks naratif baik itu kutipan langsung maupun tidak langsung, serta dalam bentuk tabel.

\section{GAMBARAN UMUM DAN LOKASI PENELITIAN}

\section{Kelompok Tani Berkah Tani}

Kelompok Tani Berkah Tani merupakan kelompok tani yang berada di Desa Pangauban, Kecamatan Cisurupan Kabupaten Garut Jawa Barat. Poktan Berkah Tani berfokus pada komoditas kopi, yaitu kopi arabika.

Poktan Berkah tani telah berdiri selama enam tahun. Asal mula berdiri Poktan ini adalah ingin memajukan masyarakat Desa Pangauban yang menanam kopi. Poktan Berkah Tani ditetapkan sebagai salah satu kelompok tani kopi terbaik di Kabupaten Garut.

Poktan Berkah Tani memiliki anggota sebanyak 70 orang. Poktan ini telah melakukan pelatihan dna penyuluhan sebanyak 15 kali pertemuan dengan tema yang berbeda setiap pertemuanya. Setiap pertemuan anggota yang diikut sertakan hanya sebanyak 25 orang, sehingga untuk pelatihan dan penyuluhan anggota kelompok bergantian untuk mengikutinya.

\section{Kelompok Tani Pamulihan}

Kelompok tani Pamulihan merupakan salah satu kelompok tani yang berfokus pada komoditas kopi. Kopi yang ditanam adalah kopi arabika, karena kopi arabika tumbuh subur dibandingkan 
dengan jenis kopi lainnya. Poktan Pamulihan berada di Desa Pamulihan Kecamatan Cisurupan Kabupaten Garut Jawa Barat. Poktan Pamulihan telah berdiri selama sembilan tahun. Jumlah anggota pada Poktan Pamulihan adalah sebanyak 65 orang. awal mula didirikannya Poktan Pamulihan adalah agar mendapat bantuan dari pemerintah.

Kegiatan yang dilakukan dilakukan oleh anggota kelompok tani selain melakukan penanaman adalah mengikuti pelatihan dan penyuluhan yang diadakan oleh Poktan Pamulihan. Kegiatan tersebut biasanya dilakukan ditempat ketua kelompok. Pelatihan dan penyuluhan biasanya diisi oleh dua orang dari bidang penyuluhan yang memegang daerah tersebut. Setiap pertemuan ada batas orang yang mengikutinya yaitu 20 orang. Orang yang mengikuti pelatihan dan penyuluhan tersebut adalah orang yang telah dipilih terlebih dahulu.

\section{Kelompok Tani Pelita VB}

Kelompok tani yang terdapat di Desa Pamulihan, Kecamatan Cisurupan, Kabupaten Garut, Jawa Barat salah satunya adalah kelompok tani komoditas teh. Kelompok tani teh tersebut adalah kelompok tani teh Pelita VB. Teh yang ditanam oleh kelompok tani tersebut ada beberapa jenisnya seperti kiara, tri 25 dan lain sebagainya. Masyarakat Desa Pamulihan sudah menanam teh sejak lama, khususnya ketua kelompok Pelita VB sudah menanam sejak tahun 1961. Kelompok tani teh Pelita VB sudah berdiri 10 tahun. Berdirinya Poktan Pelita VB adalah membantu masyarakat desa sekitar yang menanam teh. Poktan Pelita VB memiliki anggota 20 orang. Awalnya kelompok Pelita VB memiliki banyak anggota tetapi ada beberapa anggota yang keluar dikarenakan sudah tidak menanam teh lagi dan ada beberapa yang telah meninggal dunia. Ketua Poktan Pelita VB dari awal berdiri hingga sekarang diketuai oleh Bapak Daban. Setiap kegiatan yang dilakukan oleh Poktan, ketua dibantu oleh bendahara dan sekertaris.

\section{Kelompok Tani Melati}

Kelompok tani teh di Desa Pangauban diberi nama kelompok tani Melati. Poktan Melati telah berdiri sejak tahun 2014 atau selama 6 tahun. Kelompok ini menjadi salah satu kelompok teh terbaik menurut Dinas Pertanian Kabupaten Garut. Poktan Melati berfokus pada komoditas teh, dimana teh yang ditanam berbeda-beda jenisnya ada teh tri 25 , kiara, dan lain sebagainya. diantaranya adalah bibit, pupuk, alat-alat pertanian, penyuluhan serta pelatihan. Setiap penyuluhan dan pelatihan dilaksanakan, setiap tema pertemuannya berbeda-beda. Tema tersebut seperti pemetikan, pemupukan, hama, dan lain sebagainya. Setiap pertemuan biasanya diisi oleh 1-2 orang penyuluh yang memegang Kecamatan Cisurupan. Penyuluhan dan pelatihan biasanya dilakukan di tempat ketua kelompok. Selama berdiri dari awal hingga sekarang Poktan Melati masih diketuai oleh Bapak Ismail. Bapak Ismail mencetuskan untuk dibentuk kelompok tani adalah untuk membantu masyrakat sekitar yang menanam komoditas teh.

\section{HASIL DAN PEMBAHASAN}

\section{HUBUNGAN DINAMKA KELOMPOK DENGAN KEBERHASILAN USAHA}

\section{Hubungan Norma Kelompok dengan Keberhasilan Usaha}

Keberadaan norma menurut Suminar (2008) berfungsi sebagai pedoman dalam bertingkah laku untuk menentukan perbuatan yang harus dilakukan oleh anggota dan yang tidak boleh dilakukan

oleh anggota, dimana hal tersebut untuk mencapai tujuan kelompok.

Tabel 1 Hubungan norma kelompok dengan kebehasilan usaha pada kelompok tani teh dan kopi

\begin{tabular}{|c|c|c|}
\hline \multirow{3}{*}{$\begin{array}{l}\text { Norma } \\
\text { kelompok }\end{array}$} & \multicolumn{2}{|c|}{ Keberhasilan usaha } \\
\hline & $\begin{array}{l}\text { Pemenuhan } \\
\text { kebutuhan } \\
\text { sosial }\end{array}$ & $\begin{array}{l}\text { Pemenuhan } \\
\text { kebutuhan } \\
\text { materi }\end{array}$ \\
\hline & rs & rs \\
\hline Berkah tani & 0.354 & -0.147 \\
\hline Pamulihan & $-0.512 *$ & 0.327 \\
\hline Melati & -0.093 & -0.412 \\
\hline Pelita VB & 0.439 & -0.119 \\
\hline
\end{tabular}


Uji korelasi pada tabel di atas untuk norma kelompok dan pemenuhan kebutuhan sosial pada Poktan Berkah Tani menghasilkan nilai sebesar 0.354. Nilai tersebut menunjukkan bahwa hubungan antara norma kelompok dan pemenuhan kebutuhan sosial termasuk ke dalam hubungan yang cukup. Sementara untuk hasil uji korelasi antara norma kelompok dengan pemenuhan kebutuhan materi pada Poktan Berkah Tani menghasilkan nilai sebesar -0.147. Nilai tersebut menunjukkan bahwa hubungan antara norma kelompok dengan pemenuhan kebutuhan materi pada Poktan Berkah Tani termasuk ke dalam hubungan yang sangat lemah. Tanda negatif pada hasil uji korelasi tersebut menunjukkan bahwa hubungan antara norma kelompok dengan pemenuhan kebutuhan materi memiliki hubungan yang tidak searah.

Norma kelompok dan pemenuhan kebutuhan sosial pada Poktan Pamulihan menghasilkan nilai sebesar -0.512*. Nilai tersebut menunjukkan bahwa hubungan antara norma kelompok dan pemenuhan kebutuhan sosial menunjukkan hubungan yang kuat. Tanda negatif memiliki makna bahwa hubungan antara norma kelompok dengan pemenuhan kebutuhan sosial tidak searah. Hasil uji korelasi antara norma kelompok dengan pemenuhan kebutuhan materi pada Poktan Pamulihan menghasilkan nilai sebesar 0.327 . Nilai tersebut menunjukkan bahwa hubungan antara norma kelompok dengan pemenuhan kebutuhan materi termasuk ke dalam hubungan yang cukup. Hasil uji korelasi untuk norma kelompok dan pemenuhan kebutuhan sosial pada Poktan Melati menghasilkan nilai sebesar -0.093. Nilai tersebut memiliki makna bahwa hubungan antara norma kelompok dan pemenuhan kebutuhan sosial pada Poktan Melati termasuk ke dalam hubungan yang sangat lemah. Tanda negatif berarti hubungan antara norma kelompok dan pemenuhan kebutuhan sosial tidak searah. Sementara itu, hasil uji korelasi antara norma kelompok dengan pemenuhan kebutuhan materi pada Poktan Melati menghasilkan nilai sebesar -0.412. Nilai tersebut memiliki makna bahwa pada Poktan Melati hubungan antara norma kelompok dan pemenuhan kebutuhan sosial termasuk ke dalam hubungan yang cukup. Tanda negatif pada hasil uji korelasi menunjukkan bahwa hubungan norma kelompok dan pemenuhan kebutuhan materi termasuk hubungan yang tidak searah.

Hasil uji korelasi pada Poktan Pelita VB untuk norma kelompok dan pemenuhan kebutuhan sosial menghasilkan nilai sebesar 0.439. Nilai tersebut memiliki makna bahwa hubungan norma kelompok dan pemenuhan kebutuhan sosial memiliki hubungan yang cukup. Hasil uji korelasi pada Poktan Pelita VB untuk norma kelompok dan pemenuhan kebutuhan materi menghasilkan nilai sebesar -0.119. Nilai tersebut menunjukkan bahwa hubungan norma kelompok dengan pemenuhan kebutuhan materi termasuk ke dalam hubungan yang sangat lemah. Tanda negatif disini memiliki arti bahwa hubungan antara norma kelompok dengan pemenuhan kebutuhan materi tidak searah.

\section{Hubungan Peran Kelompok dengan Keberhasilan Usaha}

Peran seseorang harus dilaksanakan untuk mempertahankan kedinamisan. Menurut Forsyth (2019), peran dikaitkan dengan suatu posisi atau suatu status anggota dalam kelompok. Konsep peran menjelaskan perubahan beberapa orang yang menjadi anggota kelompok.

Tabel 2 Hubungan peran kelompok dengan keberhasilan usaha pada kelompok tani teh dan kopi

\begin{tabular}{llr}
\hline \multirow{2}{*}{$\begin{array}{l}\text { Peran } \\
\text { kelompok }\end{array}$} & \multicolumn{2}{l}{ Keberhasilan usaha } \\
\cline { 2 - 3 } & $\begin{array}{l}\text { Pemenuhan } \\
\text { kebutuhan } \\
\text { sosial }\end{array}$ & $\begin{array}{l}\text { Pemenuhan } \\
\text { kebutuhan } \\
\text { materi }\end{array}$ \\
\cline { 2 - 3 } & rs & rs \\
\hline Berkah tani & 0.00 & 0.214 \\
Pamulihan & $-0.689 * *$ & -0.408 \\
Melati & 0.357 & $-0.750 * *$ \\
Pelita VB & -0.130 & 0.248 \\
\hline
\end{tabular}

Uji korelasi antara peran kelompok dengan pemenuhan kebutuhan sosial pada Poktan Berkah Tani menghasilkan nilai sebesar 0.00 . Nilai tersebut memiliki makna bahwa hubungan antara peran kelompok dengan pemenuhan kebutuhan sosial termasuk hubungan yang sangat lemah. Sementara, hasil uji korelasi antara peran kelompok dengan pemenuhan kebutuhan materi pada Poktan Berkah Tani menghasilkan nilai sebesar 0.214. nilai tersebut menunjukkan bahwa 
hubungan antara peran kelompok dengan pemenuhan kebutuhan materi termasuk hubungan yang sangat lemah.

Hasil uji korelasi antara peran kelompok dengan pemenuhan kebutuhan sosial pada Poktan Pamulihan menghasilkan nilai sebsar $-0.698 * *$. Nilai tersebut menunjukkan bahwa hubungan antara peran kelompok dengan pemenuhan keberhasilan usaha memiliki hubungan yang kuat. Tanda negatif menunjukkan bahwa hubungan antara peran kelompok dengan pemenuhan kebutuhan usaha tidak searah. Sementara untuk hasil uji korelasi antara peran kelompok dengan pemenuhan kebutuhan materi pada Poktan Pamulihan menghasilkan nilai sebesar -0.408. Nilai tersebut menunjukkan bahwa hubungan antara peran kelompok dengan pemenuhan kebutuhan materi termasuk ke dalam hubungan yang cukup. Tanda negatif pada hasil uji korelasi menunjukkan bahwa hubungan antara peran kelompok dengan pemenuhan kebutuhan materi termasuk ke dalam hubungan yang tidak searah.

Pada Poktan Melati untuk hasil uji korelasi antara peran kelompok dengan pemenuhan kebutuhan sosial menghasilkan nilai sebesar 0.357. Nilai tersebut menunjukkan bahwa hubungan antara peran kelompok dengan pemenuhan kebutuhan sosial termasuk ke dalam hubungan yang cukup. Sementara untuk hasil uji korelasi antara peran kelompok dengan pemenuhan kebutuhan materi pada Poktan Melati menghasilkan nilai sebesar $-0.750^{* *}$. Nilai tersebut menunjukkan bahwa hubungan antara peran kelompok dengan pemenuhan kenutuhan materi termasuk hubungan yang kuat. Tanda negatif pada hasil uji korelasi menunjukkan bahwa hubungan peran kelompok dengan pemenuhan kebutuhan materi termasuk hubungan yang tidak searah.

Pada Poktan Pelita VB untuk hasil uji korelasi antara peran kelompok dengan pemenuhan kebutuhan sosial menghasilkan nilai sebesar -0.130. Nilai tersebut menunjukkan bahwa hubungan antara peran kelompok dengan pemenuhan kebutuhan sosial termasuk ke dalam hubungan yang sangat lemah. Tanda negatif disini memiliki makna bahwa hubungan antara peran kelompok dengan pemenuhan kebutuhan sosial termasuk ke dalam hubungan yang tidak searah. Sementara hasil uji korelasi antara peran kelompok dengan pemenuhan kebutuhan materi pada Poktan Pelita VB menghasilkan nilai sebesar 0.248. Nilai tersebut menunjukkan bahwa hubungan antara peran kelompok dengan pemenuhan kebutuhan materi termasuk hubungan yang sangat lemah.

\section{Hubungan Kohesivitas Kelompok dengan Keberhasilan Usaha}

Tingkatan yang menunjukkan anggota kelompok saling terkait satu sama lain menunjuk pada kohesivitas kelompok. Kohesivitas kelompok merupakan derajat ketertarikan anggota yang merasa satu dengan anggota lainnya. Hasil penelitian Novitasari (2016) menyatakan bahwa semakin kompak suatu kelompok maka anggota akan mengarah pada tujuan-tujuan kelompok yang telah ditetapkan sebelumnya.

Tabel 3 Hubungan kohesivitas kelompok dengan keberhasilan usaha pada kelompok tani teh dan kopi

\begin{tabular}{llr}
\hline \multirow{2}{*}{$\begin{array}{l}\text { Kohesivitas } \\
\text { kelompok }\end{array}$} & Keberhasilan usaha & \\
\cline { 2 - 3 } & $\begin{array}{l}\text { Pemenuhan } \\
\text { kebutuhan } \\
\text { sosial }\end{array}$ & $\begin{array}{l}\text { Pemenuhan } \\
\text { kebutuhan } \\
\text { materi }\end{array}$ \\
\cline { 2 - 3 } & rs & rs \\
\hline Berkah tani & 0.408 & -0.279 \\
Pamulihan & 0.387 & 0.1 \\
Melati & $0.792^{* *}$ & $-0.477^{* *}$ \\
Pelita VB & 0.123 & 0.132 \\
\hline
\end{tabular}

Hasil uji korelasi untuk kohesivitas kelompok dan pemenuhan kebutuhan sosial Poktan Berkah Tani menghasilkan nilai sebesar 0.408 . Nilai tersebut memiliki makna bahwa hubungan antara kohesivitas kelompok dengan pemenuhan kebutuhan sosial termasuk ke dalam hubungan yang cukup. Hasil uji korelasi antara kohesivitas kelompok dengan pemenuhan kebutuhan materi pada Poktan Berkah Tani menghasilkan nilai sebesar -0.279. Nilai tersebut menunjukkan bahwa hubungan antara kohesivitas kelompok dengan pemenuhan kebutuhan materi termasuk ke dalam hubungan yang cukup. Tanda negatif pada hasil uji korelasi menunjukkan bahwa hubungan kohesivitas kelompok dengan pemenuhan kebutuhan materi termasuk hubungan yang tidak searah. 
Poktan Pamulihan menghasilkan nilai 0.387 untuk hasil uji korelasi antara kohesivitas kelompok dan pemenuhan kebutuhan sosial. Nilai tersebut menunjukkan bahwa hubungan antara kohesivitas kelompok dan pemenuhan kebutuhan sosial termasuk hubungan yang cukup. Sementara untuk hasil uji korelasi pada Poktan Pamulihan untuk kohesivitas kelompok dengan pemenuhan kebutuhan materi menghasilkan nilai sebesar 0.1. Hasil uji korelasi tersebut menunjukkan bahwa hubungan antara kohesivitas kelompok dengan pemenuhan kebutuhan materi termasuk ke dalam hubungan yang sangat lemah.

Hasil uji korelasi untuk Poktan melati untuk kohesivitas kelompok dan pemenuhan kebutuhan sosial menghasilkan nilai sebesar $0.792 * *$. Nilai tersebut menunjukkan bahwa hubungan antara kohesivias kelompok dan pemenuhan kebutuhan sosial memiliki hubungan yang sangat kuat. Sementara hasil uji korelasi yang pada Poktan Melati untuk kohesivitas kelompok dengan pemenuhan kebutuhan materi menunjukkan hasil sebesar - 0.477**. Hasil uji korelasi tersebut membuktikan bahwa hubungan antara kohesivitas kelompok dengan pemenuhan kebutuhan materi termasuk ke dalam hubungan yang cukup.

Hasil uji korelasi pada Poktan Pelita VB untuk kohesivitas kelompok dengan pemenuhan kebutuhan sosial menunjukkan hasil sebesar 0.123. Nilai tersebut memiliki arti bahwa hubungan antara kohesivitas kelompok dan pemenuhan kebutuhan sosial termasuk ke dalam hubungan yang sangat lemah. . Hasil uji korelasi yang pada Poktan Pelita VB untuk kohesivitas kelompok dengan pemenuhan kebutuhan materi menunjukkan hasil sebesar 0.132. Hasil uji korelasi tersebut membuktikan bahwa hubungan antara kohesivitas kelompok dengan pemenuhan kebutuhan materi termasuk ke dalam hubungan yang sangat lemah.

\section{Hubungan Power Kelompok dengan Keberhasilan Usaha}

Menurut Forsyth (2019), kekuasaan adalah kemampuan individu untuk mengendalikan dan memengaruhi individu lainnya.

Tabel 4 Hubungan power kelompok dengan keberhasilan usaha pada kelompok tani teh dan kopi

\begin{tabular}{|c|c|c|}
\hline \multirow{4}{*}{$\begin{array}{l}\text { Power } \\
\text { kelompok }\end{array}$} & \multicolumn{2}{|l|}{ Keberhasilan usaha } \\
\hline & Pemenuhan & Pemenuhan \\
\hline & $\begin{array}{l}\text { kebutuhan } \\
\text { sosial }\end{array}$ & $\begin{array}{l}\text { kebutuhan } \\
\text { materi }\end{array}$ \\
\hline & $\mathrm{rs}$ & Rs \\
\hline Berkah tani & 0.345 & 0.027 \\
\hline Pamulihan & 0.334 & 0.302 \\
\hline Melati & $-0.729 * *$ & $0.477 *$ \\
\hline Pelita VB & -0.063 & $0.654 * *$ \\
\hline
\end{tabular}

Hasil uji korelasi yang dihasilkan pada Poktan Berkah Tani untuk power kelompok dan pemenuhan kebutuhan sosial menghasilkan nilai sebesar 0.345. Nilai tersebut menunjukkan bahwa hubungan antara power kelompok dengan pemenuhan kebutuhan sosial termasuk ke dalam hubungan yang cukup. Sementara untuk uji korelasi pada Poktan Berkah Tani menunjukkan hasil sebesar 0.027. Hasil uji korelasi tersebut menunjukkan bahwa hubungan antara power kelompok dengan pemenuhan kebutuhan materi termasuk ke dalam hubungan yang sangat lemah.

Hasil uji korelasi antara power kelompok dengan pemenuhan kebutuhan sosial pada Poktan Pamulihan menghasilkan nilai sebesar 0.334. Nilai tersebut menunjukkan bahwa hubungan antara power kelompok dengan pemenuhan kebutuhan sosial termasuk ke dalam hubungan yang cukup. Sementara untuk hasil uji korelasi antara power kelompok dengan pemenuhan kebutuhan materi pada Poktan Pamulihan menghasilkan nilai sebesar 0.302. Nilai tersebut menunjukkan bahwa hubungan antara power kelompok dengan pemenuhan kebutuhan materi termasuk hubungan yang cukup.

Hasil uji korelasi yang telah dilakukan pada Poktan Melati untuk power kelompok dan pemenuhan kebutuhan sosial menghasilkan nilai sebesar -0.792**. Nilai tersebut membuktikan bahwa hubungan antara power kelompok dengan pemenuhan kebutuhan sosial pada Poktan Pamulihan termasuk hubungan yang kuat. Tanda negatif disini memiliki arti bahwa hubungan antara power kelompok dengan pemenuhan kebutuhan sosial tidak searah. Sementara untuk hasil uji korelasi antara power kelompok dengan pemenuhan kebutuhan materi pada Poktan Melati menghasilkan 
nilai sebesar 0.477. Hasil uji korelasi tersebut menunjukkan bahwa hubungan antara power kelompok dengan pemenuhan kebutuhan materi termasuk ke dalam hubungan yang cukup.

Hasil uji korelasi yang telah dilakukan pada Poktan Pelita VB untuk power kelompok dengan pemenuhan kebutuhan sosial menghasilkan nilai sebesar -0.063. Nilai tersebut menunjukkan bahwa hubungan yang terjasdi antara power kelompok dengan pemenuhan kebutuhan sosial pada Poktan Pelita VB termasuk ke dalam hubungan yang sangat lemah. Tanda negatif membukikan bahwa hubungan antara keduanya tidak searah. Hasil uji korelasi antara power kelompok dengan pemenuhan kebutuhan materi pada Potan Pelita VB menghasilkan nilai sebesar 0.654**. Nilai tersebut menunjukkan bahwa hubungan antara power kelompok dengan pemenuhan kebutuhan materi termasuk hubungan yang kuat.

\section{Hubungan Grouptink dengan Keberhasilan Usaha}

Menurut Ardhrianti (2016), groupthink didefinisikan sebagai satu situasi dalam proses pengambilan keputusan yang menunjukkan tumbuhnya kemerosotan efisiensi mental, pengujian realitas, dan penilaian moral yang disebabkan oleh tekanan-tekanan kelompok

Tabel 5 Hubungan groupthink dengan keberhasilan usaha pada kelompok tani teh dan kopi

\begin{tabular}{llr}
\hline & \multicolumn{2}{c}{ Keberhasilan usaha } \\
\cline { 2 - 3 } Groupthink & $\begin{array}{l}\text { Pemenuhan } \\
\text { kebutuhan } \\
\text { sosial }\end{array}$ & $\begin{array}{l}\text { Pemenuhan } \\
\text { kebutuhan } \\
\text { materi }\end{array}$ \\
\cline { 2 - 3 } & rs & rs \\
\hline Berkah & 0.00 & -0.326 \\
tani & -0.185 & -0.419 \\
Pamulihan & 0.112 & $-0.724^{* *}$ \\
Melati & -0.153 & 0.072 \\
Pelita VB & & \\
\hline
\end{tabular}

Hasil uji korelasi antara tingkat groupthink dengan pemenuhan kebutuhan sosial pada Poktan Berkah Tani menghasilkan nilai sebesar 0.00. Nilai tersebut menunjukkan bahwa hubungan antara tingkat groupthink dengan pemenuhan kebutuhan sosial memiliki hubungan yang sangat lemah. Hasil uji korelasi antara tingkat groupthink dengan pemenuhan kebutuhan materi pada Poktan Berkah Tani menghasilkan nilai sebesar -0.326. Nilai tersebut menunjukkan bahwa hubungan antara tingkat groupthink dengan pemenuhan kebutuhan materi memiliki hubungan yang cukup. Pada hasil uji korelasi menghasilkan nilai yang negatif, dimana hal terebut menunjukkan bahwa hubungan antara tingkat groupthink dengan pemenuhan kebutuhan materi memiliki hubungan yang tidak searah.

Hasil uji korelasi antara tingkat groupthink dengan pemenuhan kebutuhan sosial pada Poktan Pamulihan menghasilkan nilai sebesar -0.185. Nilai tersebut menunjukkan bahwa hubungan antara tingkat groupthink dengan pemenuhan kebutuhan sosial memiliki hubungan yang sangat lemah.

Pada hasil uji korelasi tersebut menghasilkan nilai yang negatif, dimana hal tersebut menunjukkan bahwa hubungan antara tingkat groupthink dengan pemenuhan kebutuhan sosial memiliki hubungan yang tidak searah. Hasil uji korelasi antara tingkat groupthink dengan pemenuhan kebutuhan materi pada Poktan Pamulihan menghasilkan nilai sebesar - 0.419. Nilai tersebut memiliki arti bahwa hubungan antara tingkat groupthink dengan pemenuhan kebutuhan materi memiliki hubungan yang cukup.

Hasil uji korelasi antara groupthink dengan pemenuhan kebutuhan sosial pada Poktan Melati menghasilkan nilai sebesar 0.112. Nilai tersebut menunjukkan bahwa hubungan antara tingkat groupthink dan pemenuhan kebutuhan sosial memiliki hubungan yang sangat lemah.

Hasil uji korelasi antara tingkat groupthink dengan pemenuhan kebutuhan materi pada Poktan Melati menghasilkan nilai sebesar - 0.724**. Nilai tersebut menunjukkan bahwa hubungan antara tingkat groupthink dengan pemenuhan kebutuhan materi memiliki hubungan yang kuat. Pada hasil uji korelasi menghasilkan nilai yang negatif, dimana hal tersebut menunjukkan bahwa hubungan antara tingkat groupthink dengan pemenuhan kebutuhan materi memiliki hubungan yang tidak searah. 
Hasil uji korelasi antara tingkat groupthink dengan pemenuhan kebutuhan sosial pada Poktan Pelita $\mathrm{Vb}$ menghasilkan nilai sebesar -0.153 . Nilai tersebut menunjukkan bahwa hubungan antara tingkat groupthink dengan pemenuhan kebutuhan sosial memiliki hubungan yang sangat lemah. Pada hasil uji korelasi tersebut menghasilkan nilai yang negatif, dimana hal tersebut menunjukkan bahwa hubungan antara tingkat groupthink dengan pemenuhan kebutuhan sosial memiliki hubungan yang tidak searah. Uji korelasi antara tingkat groupthink dengan pemenuhan kebutuhan materi pada Poktan Pelita VB menghasilakan nilai sebesar 0.072. Nilai tersebut menunjukkan bahwa hubungan antara tingkat groupthink dengan pemenuhan kebutuhan materi memiliki hubungan yang sangat lemah.

\section{KESIMPULAN}

Berdasarkan hasil penelitian mengenai dinamika kelompok dan keberhasilan usaha pada petani teh dan kopi di Garut, dapat dirumuskan kesimpulan sebagai berikut: Hubungan antara dinamika kelompok dengan keberhasilan usaha hanya beberapa yang signifikan. Hubungan yang signifikan diantaranya adalah norma kelompok dengan pemenuhan kebutuhan sosial pada Poktan Pamulihan, peran kelompok dengan pemenuhan kebutuhan sosial pada Poktan Pamulihan, kohesivitas kelompok dengan pemenuhan kebutuhan sosial pada Poktan Melati, power kelompok dengan pemenuhan kebutuhan sosial pada Poktan Melati, peran kelompok dengan pemenuhan kebutuhan materi pada Poktan Melati, kohesivitas kelompok dengan pemenuhan kebutuhan materi pada Poktan Melati, power kelompok dengan pemenuhan kebutuhan materi pada Poktan Melati dan Pelita VB, serta groupthink dengan pemenuhan kebutuhan materi pada Poktan Melati.

\section{Saran}

Penulis megakui bahwa hasil penelitian yang ada dalam penelitian ini memiliki keterbatasan diantaranya, pada unit analisis penulis tidak menggunakan kelompok. Dengan demikian, untuk penelitian selanjutnya, penggunaan unit analisis pada tingkat kelompok menjadi penting untuk dikaji lebih lanjut mengingat variabel dependent yaitu dinamika keompok mencerminkan karakterikstik yang ada pada tingkat dinamika kelompok.

Pemilihan responden pada penelitian ini terlalu homogen dilihat dari karakteristiknya dengan jumlah yang terbilang sedikit, sehingga data yang terkumpul tidak menyebar normal yang mengakibatkan sejumlah variabel tidak berhubungan secara signifikan. Dengan demikian, pada penelitian selanjutnya, pemilihan karakteristik responden dan jumlah sampel yang digunakan menjadi penting untuk dipertimbangkan

\section{DAFTAR PUSTAKA}

Adhrianti L. 2016. Kondisi pendahulu dan gejala groupthink dalam dinamika komunikasi politik. Jurnal Communicate [Internet]. [Diunduh 2019 Okt 16]. 2(1): 21-26. Tersedia pada: https://media.neliti.com/media/publications/233666-kondisi-pendahulu-dan-gejalagroupthink-0373118d.pdf

Anisi AF, Yunasaf Unang, Winaryanto S. 2015. Hubungan dinamika kelompok dengan keberhasilan usaha ternak kambing Peranakan etawah. E-Journal Mahasiswa [Internet]. [Diunduh 2019 Sep 5]. 4(4): 1-13. Tersedia pada: http://journal.unpad.ac.id/ejournal/article/view/8055/3640

Arimbawa P. 2004. Peran kelompok untuk meningkatkan kemampuan anggota dalam penerapan inovasi teknologi [Tesis] Bogor (ID): Institut Pertanian Bogor. Terdapat pada https://repository.ipb.ac.id/bitstream/handle/123456789/10912/2008ssu.pdf?sequence=2\&i sAllowed=y

[BPS] Badan Pusat Statistik. 2017. Ekspor Kopi. Jakarta (ID): BPS. 2018. Ekspor Teh. Jakarta (ID): BPS.

Forsyth DR. 2019. Group Dynamics. Ed ke-7. Boston (US): Cengage.

Istiyani A. 2016. Peranan kelompok tani mengingkatkan produktivitas usahatani anggota [Skripsi]. Bogor (ID): Institut Pertanian Bogor. Terdapat pada https://repository.ipb.ac.id/handle/123456789/92219

Novitasari IC. 2016. Karakterisktik anggota, iklim komunikasi, peran kepemimpinan dan kohesivitas kelompok masyarakat pengawas kejung samudra [Skripsi]. Bogor (ID: Institut Pertanian Bogor. Tersedia pada https://repository.ipb.ac.id/handle/ 123456789/86844 
Pratisthita RN, Munandar M, Homzah S. 2014. Peran modal sosial dalam menunjang dinamika kelompok peternak sapi perah. Jurnal Ilmu Ternak [Internet]. [Diunduh 2019 Sep 5]. 1(10): 52-57. Tersedia pada http://jurnal.unpad.ac.id/jurnalilmuternak/article/view/5148/2574

Reijntjes C, Haverkort B, Bayer AW._1999. Pertanian masa depan._Yogyakarta (ID): Kanisius.

Rimbawati, Fatchiya A, Sugihen BG. 2018. Dinamika kelompok tani hutan agroforestry di Kabupaten Bandung. Jurnal Penyuluhan [Internet]. [Diunduh 2019 Sep 5]. 14(1): 92-103. Tersedia

pada https://journal.ipb.ac.id/index.php/jupe/article/view/17223/14483

Santosa S. 2004. Dinamika Kelompok. Jakarta(ID): Bumi Aksara.

Suminar S. 2008. Peningkatan efektivitas kelompok dalam mendukung keberhasilan program pengembangan kecamatan (PPK) [tesis]. Bogor (ID): IPB. Tersedia pada https://repository.ipb.ac.id/bitstream/handle/123456789/10912/2008ssu.pdf?sequenc $\mathrm{e}=2 \&$ is Allowed $=\mathrm{y}$

Thomas dan John. 2008. Small Group and Team Communication. Ed ke-4. New York(US): Pearson Education. 